\title{
Tribal Land Alienation—Tribal Women
}

\author{
Dr. Gatti Yellaiah ${ }^{1^{*}}$ \\ ${ }^{1}$ Assistant Director, Dr. BR Ambedkar Open University, Regional Coordinating Centre, Adilabad, AP, \\ India
}

* Gatti Yellaiah, Assistant Director, Dr. BR Ambedkar Open University, Regional Coordinating Centre, Adilabad. India

\begin{abstract}
Land is the bread winning element to most of the tribal all over the three regions of costal Andhra, Telangan, and even in Rayalaseem of AP more specifically, if it comes to the case of women it is applicable to all over the world women in restriction, because almost all the tribal depends on land since they have less literacy rate compare to the other population of the state, so they are ultimately depends on land and forest which is readily available to them. There are complex issues of lad acts, and their own family systems have a great impact on their social life and especially on the life of tribal female.
\end{abstract}

\section{Keywords}

land, tribal, women, social, acts, system

\section{Introduction}

The tribal people rights have gained significance in the recent times. As a human they are people who live in tribal lands gain a same set of rights like other common people in the society. Being the citizens of the same nation they entitle to several privileges in the same way. Their issues have come to a conclusion in recent time. Human rights are those conditions which are inherent to nature and without which one cannot live as a human being. These rights and fundamental freedoms allow one to develop fully and use one's human qualities, intelligence, talents and conscience to satisfy one's spiritual, physical, social and other needs. They are based on human kind's increasing demand for life in which the inherent dignity and worth of each human being will receive respect and protection.

\section{Objectives}

The main objective of this paper is

- $\quad$ To study the problems of tribal women and tribal lands

- $\quad$ To understand the socio-economic conditions of the tribal in Andhra Pradesh. 


\section{Research Methodology}

The data has collected based on primary and as well as secondary sources. Most of the data has collected from the secondary sources.

\section{Discussion}

The human rights for women are inalienable, integral and individual part of Universal declaration Human Rights. The Universal Declaration of Human Rights and Convention on elimination of all forms of discrimination against to women [CEDAW] do faster rights of women. On the other hand equality of sexes in enshrined is the constitution of India as the fundamental right.

However, tribal women have no right and access to the property tribal women have customary rights to the land and their rights are derived through lineage to a male family land owner.

In fact the problems of tribal land alienation in the agency areas has made the tribal women empowerished and reduced them to the status of agricultural laborers. Due to deforestation the tribal women have to track to far off places for the collection forest produce and firewood and to fetch drinking water as hill streams have dried up.

Tribal women work harder than men and put their energies into harvesting crop. However they are "denied right to property" as tribal customs do not permit it. The major fall out of this is that the succession Act itself says that it will not apply to Tribals unless and until a notification is issued by the Government of India extending its applicability to Tribals.

The traditional practice is the most of tribal communities is such that the female heirs are excluded from succession unlike non-tribal Hindu women. Deprivation of land right be not only to loss of independent source of earning but also to reduction of her bargaining power. Although the judiciary has been jealous guarding the right of women in various ways, unfortunately it too has succumbed to the technicalities of law.

The legal system is not taking into account of such discrimination towards women and dismissing the plea of tribal women saying that Tribals are governed by their own customs and practices. The problem is not only limited to inadequate provisions made by the law, but it is also the attitude of tribal society which prevents women from claiming equality. Breaking the century old traditions of excluding female from beneficiaries during NT Ramarrao regime an amendment was made to the Hindu succession Act in 1986 conferring property Rights and on daughters equally with intended to protect women has not been made applicable to tribal women.

\section{Conclusion}

Hundreds of years of civilization, developed science, and emerging technology, and several activists' moments are unable to justify the Tribal in forests and hilly areas of the several parts of the world. We need to educate the women to fight for their rights. We need to prepare them mentally to face any difficult situation. It will give them to fight for their right in family and property.

Published by SCHOLINK INC. 


\section{References}

Ramdas, R. (2013). A Separate Telangana: Promises and Prospects for Tribal People. Economic and $\begin{array}{llll}\text { Political Weekly, } & \text { 118-122. } & \text { Retrieved }\end{array}$ https://www.epw.in/journal/2013/29/notes/separate-telangana.html

Rani, R. N. (2009). Socio-cultural factors that influence tribal women in decision making on farm and home activities in Khammam District of Andhra Pradesh. Mysore Journal of Agricultural Sciences, 43(2), 344-347.

Srihari, M. (2012). Role of media in tribal agriculture development-a study of Khammam district agency tribes. International Journal of Social Science and Interdisciplinary Research, 1(10), 244-253. Retrieved from http://indianresearchjournals.com/pdf/IJSSIR/2012/October/21.pdf

Yamanoorappa Yenkoba Talavar1 and Manikamma Nagindrappa. (2014). critical assessment of the scheduled tribe women empowerment in present social order, 2(2), 1-10. Retrieved from http://oldrol.lbp.world/UploadArticle/133.pdf 